\title{
MAPVOICE: COMPUTATIONAL TOOL TO AID IN LEARNING CARTOGRAPHY FOR THE VISUALLY IMPAIRED
}

\author{
MAPVOICE: Ferramenta Computacional para Auxílio na aprendizagem da
} Cartografia para Deficientes Visuais

Leonardo Carlos Barbosa ${ }^{1}$ - ORCID: 0000-0002-0377-1527

Lucilene Antunes Correia Marques de Sá

${ }^{1}$ Universidade Federal de Pernambuco-UFPE, Programa de Pós-Graduação em Ciências Geodésicas e Tecnologias da Geoinformação-PPGCGTG, Recife, Pernambuco, Brasil.

E-mail: leonardo.carlos@ufpe.br; lacms@ufpe.br.

Received in June $12^{\text {th }}, 2017$

Accepted in February $1^{\text {st }}, 2018$.

\begin{abstract}
:
In Brazil, the LDB - Law of Guidelines and Bases no 9394 (Brazil, 1996) and the PCN - National Curricular Parameters, determines that the Geography discipline is recognized as autonomous and should not be understood as a complement to other disciplines. In this way, the improvement in Geography teaching passes through cartographic literacy. The focus is on offering the student the capacity to carry out the appropriation, analysis, reflection and criticism on geographical space. In this way, this paper presents a resource that consisted of the development of the application called MapVoice. The purpose of the software is to enable Blind or visually impaired students, from basic education, in the learning of Cartography in Geography classes. MapVoice provides the understanding and interpretation of physical environments transformed into thematic maps based on data from the 2010 Brazilian Demographic Census executed by IBGE. The software used sound and image resources developed for Windows environment. The research concludes that it is necessary to prepare the infrastructure of the schools for the reception of these students, but mainly the continuing training of teachers and teaching assistants. Mapvoice was tested at the Institute of the Blind for validation, achieving a satisfactory result and making enthusiasm for the development of new researches.
\end{abstract}

Keywords: Computer application; Cartography teaching; Visually impaired.

\section{Resumo:}

No Brasil, o LDB - Lei de Diretrizes e Bases no 9394 (Brazil, 1996) e o PCN - Parâmetros Curriculares Nacionais, determina que a disciplina de Geografia é reconhecida como autônoma e não deve ser entendida como complemento de outras disciplinas. Desta forma, a melhoria do ensino da Geografia passa pela alfabetização cartográfica. O foco é oferecer ao aluno a capacidade de realizar a apropriação, análise, reflexão e crítica sobre o espaço geográfico. Desta forma, este artigo apresenta um recurso que consistiu no desenvolvimento do aplicativo chamado MapVoice.

How to cite this article: Barbosa, L.C.; de Sá, L.A.C.M. MAPVOICE: computational tool to aid in learning cartography for the visually impaired. Bulletin of Geodetic Sciences, Vol. 24, issue 1, 58-68, Jan-Mar, 2018. 
O objetivo do software é habilitar os estudantes cegos ou deficientes visuais, da educação básica, na aprendizagem de cartografia em aulas de Geografia. MapVoice fornece a compreensão e interpretação de ambientes físicos transformados em mapas temáticos com base nos dados do Censo Demográfico Brasileiro de 2010 executado pelo IBGE. O software usou recursos de som e imagem desenvolvidos para o ambiente Windows. A pesquisa conclui que é necessário preparar a infra-estrutura das escolas para a recepção desses alunos, mas principalmente a formação contínua de professores e auxiliares de ensino. O Mapvoice foi testado no Instituto de Cegos para validação, conseguindo um resultado satisfatório e entusiasmando o desenvolvimento de novas pesquisas.

Palavras-chave: Aplicativo Computacional; Ensino da Cartografia; Deficiente Visual.

\section{Introduction}

The use of computers was restricted until the last years of the twentieth century. In Brazilian public schools, there were no computer labs. When elementary students had access to information technology, they were privileged. However, today, the computer is present in people's daily lives. Another change that has been taking place in the same period is the inclusion of people with special needs in regular education. According to the Federal Constitution (Brazil, 1988) in its Article 208, It states that: "The duty of the State with the Education will be affected by guaranteeing: I compulsory and free basic education, including a free offer to all those who did not have access to it at the proper age; III-specialized educational services for the disabled, preferably in the regular education network ... " available in http://english.tse.jus.br/arquivos/federal-constitution/view. In 2006, the MEC - Ministry of Education, publishes a document that deals with the right to education, presents statistics on inclusion, and goes further by stating that there should be no discrimination or segregation of students with special needs and those families should be involved in the educational process, to transform society. The inclusion of students with special education needs becomes one of the priorities in basic education in Brazil, to ensure their full insertion in activities developed in regular classes (MEC, 2006).

According to the IBGE - Brazilian Institute of Geography and Statistics - 2010 Brazilian demographic census, there were $45,606,048$ of Brazilians, $23.9 \%$ of the total population, with some kind of disability - visual, auditory, motor and mental or intellectual. With regard to visual impairment, about 6.5 million people, being 582 thousand blind and 6 million with low vision. From this total, more than one million disabled people are students enrolled in basic education. The carriers of visual impairment in basic education were subjects of this research, with emphasis on the teaching of cartography in the geography discipline.

The classification of the visual impairment degree is thus described: - Partial blindness occurs in the individuals capable only of counting their fingers at short distance and those who only perceive shapes; - the people closest to total blindness are those who only have light perception and projection. The classification of the degree of visual impairment is thus described: - Partial blindness is the only individuals capable of counting fingers at close range and those who only perceive figures; - people closest to total blindness are those who only have light perception and projection. Perception allows the individual only the distinction between light and dark, and the projection enables the individual to identify the direction from which the light originates. Total blindness presupposes complete loss of vision, that is, vision is nonexistent. 
A person is considered blind if he or she has one of the following criteria: - The corrected vision of the best of your eyes is $6 / 60$ or less, that is, if you can see up to 6 meters, what a normal vision person can see at 60 meters, or if the widest diameter of his field of vision involves an arc not greater than 20 degrees, although his visual acuity in that narrow field may be greater than 6/60.

Pedagogically, it is defined as a blind person who, even with subnormal eyesight, needs Braille instruction and as a subnormal eye wearer who reads extended printed types or with the aid of powerful optical resources, according to (Conde, 2016).

The application proposal was to create software that aims to integrate cartography in geographic education by going to meet the Basic Education for Geography. The student must be able to use different sources of information and technological resources to acquire and build geographical knowledge. Thus, Cartography must meet the needs of students in their daily lives, especially those who have a visual impairment. For it frees them by making possible the perception of the environment where they live, overcoming the physical, economic, social and human characteristics and their transformations (Alves, 2011).

The application developed in the research used data from the 2010 Brazilian Demographic Census, which constructed a large portrait of the Brazilian population and its socioeconomic characteristics and, at the same time, the basis on which all public and private planning should be based the next decade. In this context, the school cannot fail to provide its students with access to technology. It is the school's role to insert them into the digital world. Therefore, informatics becomes relevant in the educational scenario. With its use, it is possible to increase student learning, which, if well structured, can obtain information and new knowledge.

The idea of developing an application came from accessibility software for digital environments for the visually impaired, who most often use only screen magnifiers for those with partial vision loss. In this way, students with severe visual impairment do not have access to the various means of information, thus causing a social exclusion in the learning processes. To help solve this problem, MapVoice has been developed to arouse students' attention in cartography, whether they are visually impaired or not, thanks to the sound and image resources that are used during the handling.

\section{Cartographic education for the visually impaired}

Cartography is a graphic language that materializes through cartographic documents (maps, letters, orthophotographs, models, among others). The cartographic documents are indispensable instruments in the process of interpretation and appropriation of the geographic space, both rural and urban, constituting an important means of communication. To emphasize the intrinsic relation between Geography and Cartography, as one is necessary for the understanding of the other. However, to extend the possibilities of teaching and learning because the simple teachingpedagogical instrumentalization, in little or almost nothing, would change the reality of Geography classes, according to (Enpeg, 2009). In this sense, according to the LDB - Law of Guidelines and Bases, dated December 1996, it is intended to establish a model of Special / Inclusive Education, in which all learners can enjoy a process of teaching and learning that meets their educational needs. Thus, arguments in the LDB that support the hypothesis are contemplated, such as infrastructure and adequate human resources. 
However, the precariousness of the inclusion of students with disabilities in basic education is notorious. On the one hand, there is a disregard for the adequacy of schools to receive students with special educational needs; on the other hand, there is insufficient academic training for educators to attend to this clientele. To fulfill the objectives of Education, especially democratization (education for all), it is of fundamental importance to reflect on the process of educator formation and computational resources available to effectively meet the needs of a society. Researchers who have been dedicated to studying geographic education for students with special educational needs, such as the Visually Impaired, stand out (Almeida, 2008); (Fonseca, 1999); (Rossi, 2000); (Vasconcellos, 1993); (Ventorini, 2007) and (Ventorini, 2002; Freitas, 2003).

\subsection{Classrooms}

In Silva (2006) a series of measures is presented that aims to create strategies for teaching people with Blindness and Low vision. Some of these measures are:

- Curriculum content should be the same for all students;

- The teacher should focus on explanations to be descriptive and concrete and, whenever possible, enable the blind student to manipulate objects and materials that are as close as possible to the real and that facilitate understanding and participation in activities;

- It is not only necessary to let the student listen, smell, touch and explore things, objects, but also to teach them to listen, smell, touch, for which the education of these senses is indispensable. This is important for all children, but becomes more relevant in the case of blind or low vision children due to the utility of the remaining senses in relation to objects, things and people.

\subsection{Educational resources}

It is essential that the didactic resources have visual and tactile stimuli that meet the different visual conditions. The material should have contrasting colors, textures and sizes appropriate to make it useful and meaningful. The creation of didactic resources for blind students should be based on some very important criteria for the efficiency of their use.

The representation should be as accurate as possible in relation to the model taken as the original. In addition, it should be eye-catching and pleasing to the touch. The availability of resources that at the same time meet the diverse visual conditions of the students presupposes the use of the Braille System, of extended sources and of other alternatives in the learning process. (Sá, Campos and Silva, 2007).

\subsection{Technology Resources}

Both portable audio files and the spoken book designed for use with visually impaired students are called instructional resources. 
According to Libâneo (2002), instructional resources are the means or materials that help the teacher in the organization and in the conduction of the teaching and learning process. There are currently some free Brazilian software specific for the visually impaired. The most known are:

- DOSVOX: Operating system developed by the Nucleus of Electronic Computation of the Federal University of Rio de Janeiro. It has a set of tools and own applications besides agenda, chat and interactive games. It can be downloaded free of charge from the DOSVOX project site: http://intervox.nce.ufrj.br/do. .

- VIRTUAL VISION: It is a Brazilian software developed by Micropower, in São Paulo, designed to operate with the utilities and tools of the Windows environment. It is distributed free of charge by the Bradesco Foundation and Real Bank to any user who wishes to use it. More information on the company website: Http://www.micropower.com.br.

\section{Materials and methods}

The methodological procedure employed Geoinformation Technologies. With a set of software and database, sound effects are used for communication between the application and the apprentice. Figure 1 shows the methodology used.

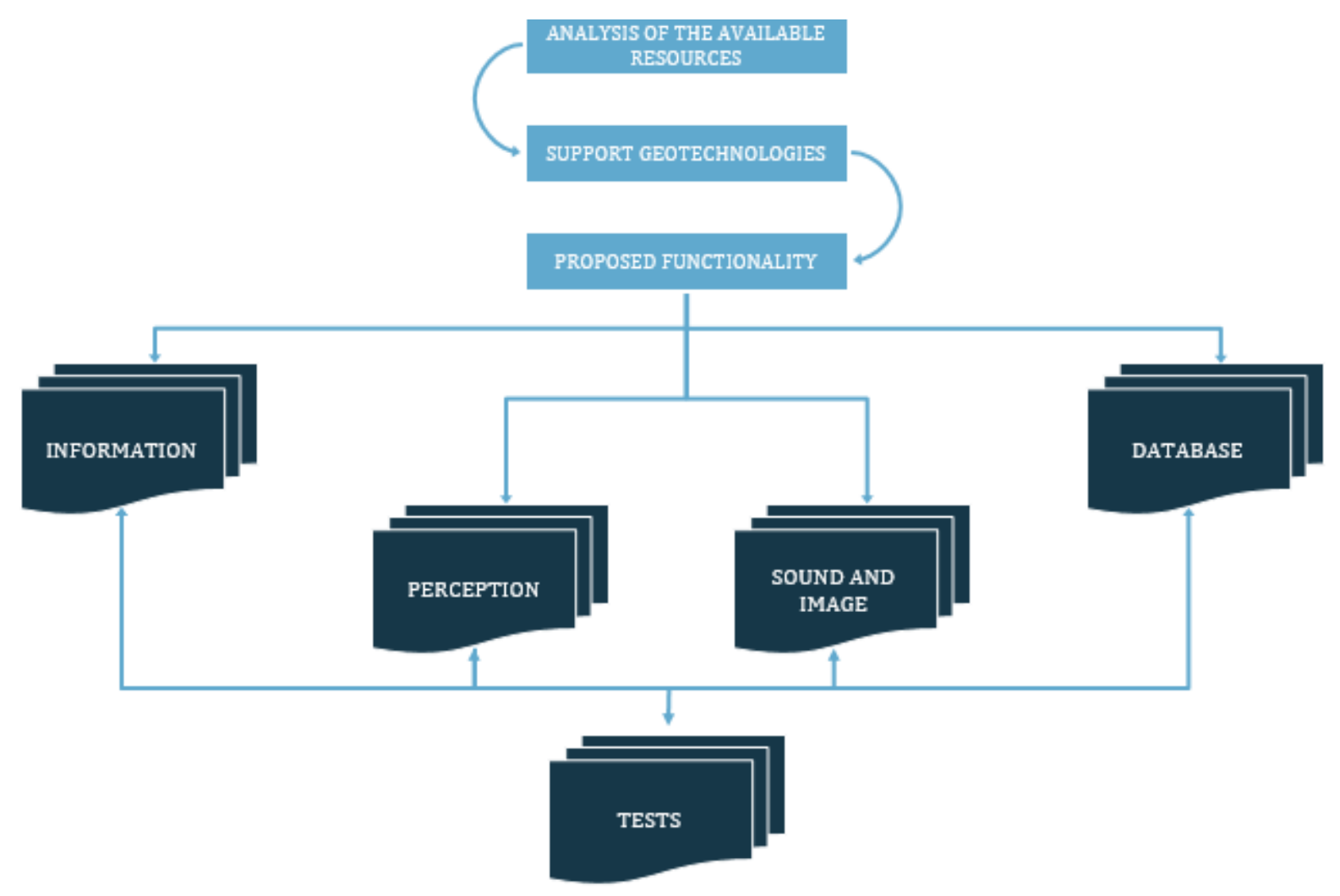

Figure 1: Steps in the development of MapVoice.

Step 1 - Web search to check the technological resources currently available; 
Step 2 - Choice of support geotechnologies: Matlab, WebCartBeta, and Loquento TTS 2.3 software were chosen.

Step 3 - In the proposed functionality were chosen the types of maps and the form of presentation to the user. The functionality is as follows.

A - Information; IBGE 2010 Census, because it is reliable information.

B - Database; The Northeast region was chosen to serve as the basis for MapVoice's implementation. The themes you entered are in Table 1.

Table 1: Themes inserted in the MapVoice Database

\begin{tabular}{l|l}
\hline \multicolumn{1}{c|}{ Themes } & \multicolumn{1}{c}{ Region Information } \\
\hline Region & Northeast \\
\hline States & \multicolumn{1}{c}{ Information by State } \\
\hline Population Data & Total Number of Inhabitants, Urban and Country \\
\hline Income & Revenue Levels (Man, Woman) \\
\hline Literacy & Women who have had Children by Degree of Instruction \\
\hline Age & Age pyramid \\
\hline
\end{tabular}

In addition to the topics in Table 1, the student has access to the database to general information about each state of the Northeast Region, with data on Area, Borders and Ruler.

C - Perception; MapVoice has the ability to identify the period of the day. Whether it is morning, afternoon or evening, the user will be greeted like: Good Morning, Good Afternoon or Good Night.

D - Sound and Image; To interact with the user, the Software uses simultaneous sound and image capability. The images (maps, graphs, figures) appear on the screen and are narrated to the user whenever the command is chosen via keyboard.

\section{The MAPVOICE}

The language used in software development was Matlab 2015. It works with a free compiler, available for download from your Mathworks developer's website: Https://www.mathworks.com/prod. The basic parameters for the functions, composition and functionalities are:

- IBGE 2010 census referring to the nine states of the Northeast with the themes seen in Table 1;

- Speech synthesis system with the voice of Fernanda, using Loquendo technology; and

- Built-in sound and image feature and interacting simultaneously during playback.

In order to adapt MapVoice to the needs of visually impaired students, it does not have a graphical interface, and its operational is through an executable file. The decision not to create an interface was taken because a graphical interface creates limitations for a visually impaired user, once the student cannot identify buttons and locations within the interface using a mouse. With the 
executable file the limitation is remedied, since the interaction is totally done via keyboard. The software splash screen is shown in Figure 2.

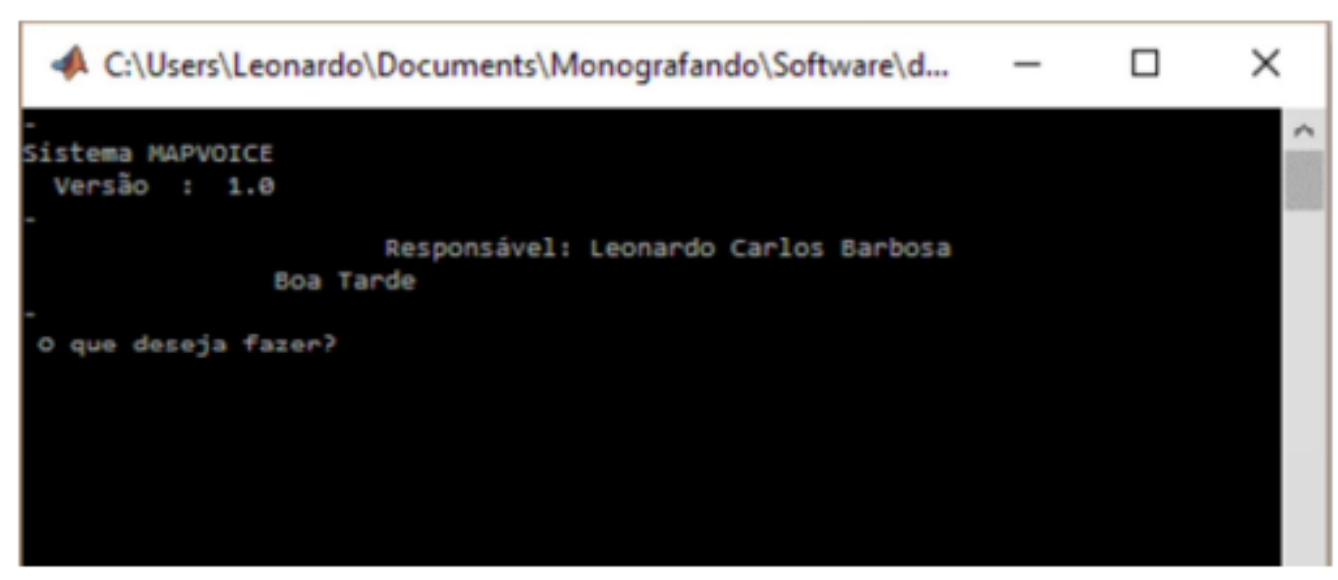

Figure 2: Mapvoice

In Figure 3, an organization chart with all the functionalities of MapVoice and its prerequisites is presented.

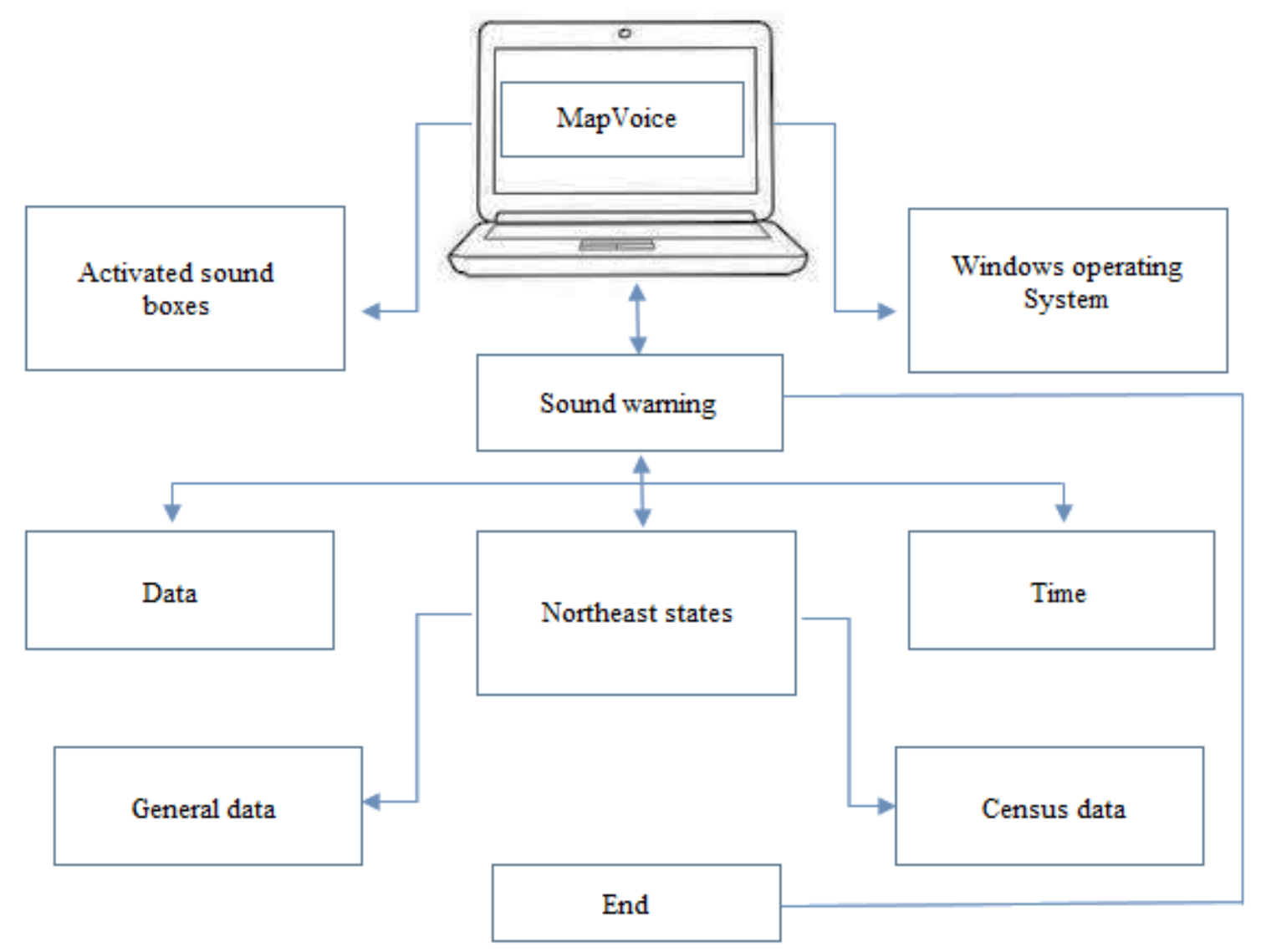

Figure 3: MapVoice Features. 
Computers running the Windows operating system from their XP version, and with activated speakers, will be able to run the software with full functionality without loss of content.

The use is simple, it is presented on the screen and the user is told the available options, which should only choose via keyboard the desired option. Once this is done, the software starts a sequence of narrations giving information about the option available and in the database.

\subsection{Testing}

With MapVoice ready, the last step was to test it with the visually impaired at Institute of the Blind Antônio Pessoa de Queiroz. For the test it was used a notebook with Windows 7 operating system and connected speaker system. During the application was used the keyboard of the notebook itself to enter the commands, since the students of the Institute already are familiar with keyboards due to SENAC - National Service Commercial Learning, which offers a free computer course for students.

The student who participated in the test, gradually lost vision from age 14 due to an accident in the rural area of Condado, Pernambuco. Today, at age 21, he perceives brightness and shapes, but his deficiency encompasses approximately $95 \%$ of vision loss, thus being considered as having a severe visual impairment. In Figure 4, a photograph of the time of the test is shown. The people involved are: from right to left: Leonardo Barbosa, (Test applicator), Severino Francisco (visually impaired elementary school student Fundamental 1), Cristina de Oliveira (employee and also visually impaired occupying the role of Braillist Technician)

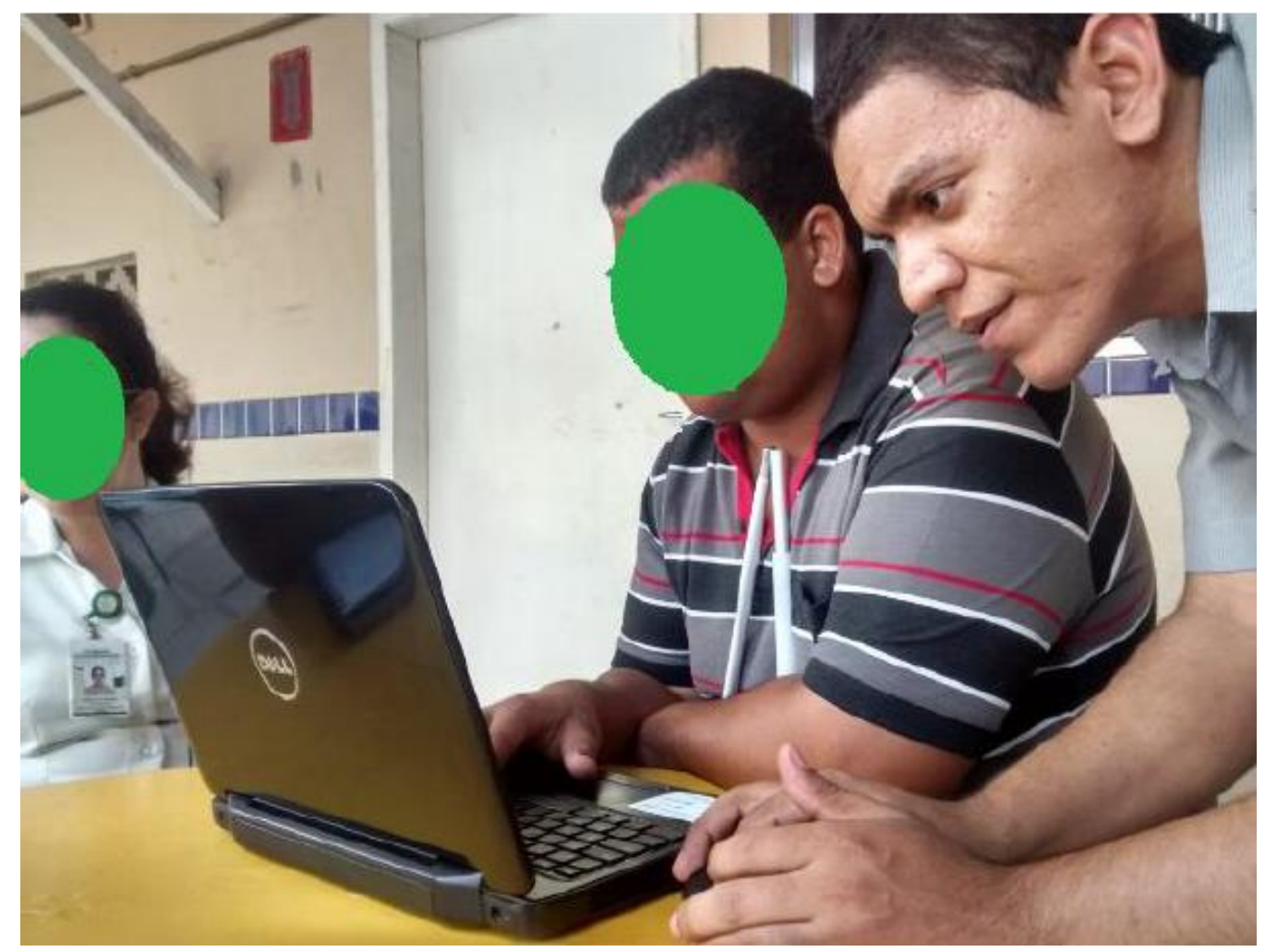

Figure 4: Application of the test at Institute of the Blind Antônio Pessoa de Queiroz. 


\section{Results and Discussions}

Throughout the test questions were asked about the evaluation of Mapvoice as a Learning resource. The feedback given by the student, Severino, and the Braillista technician, Cristina, was quite positive. They quite liked the proposal that the software provides the user. The employee Cristina gave some information that could improve the independence of students to use the software, such as:

- Instead of typing the full name of the state, only the first few letters could be entered, so there is not much dependence on knowing the keyboard to use the software.

- The software could narrate all options to the user, without having to be trained on the options.

- Feedback was very encouraging. When MapVoice was created, the idea was to have a Tutor (mother, teacher) to teach the student the options provided by the software.

However, if MapVoice already provided the options, it would not be necessary and would allow more independence for the user.

In this way, the necessary indicated modifications were made. A new version of MapVoice has been created and in this it narrates the available options, being necessary to enter only a letter to begin, or to close the program.

\subsection{Conclusions}

The research allowed the observation that it is increasingly necessary the insertion of technology in the educational environment, and should support the teaching-learning process. Several digital media are capable of bringing about changes in the paradigms of education. By uniting these tools and technology, based on pedagogical principles, a dynamic and interactive environment is created, in which the student stops being a mere spectator and becomes an active character in the process of knowledge construction in Cartography. In conclusion, the following stand out:

- MapVoice seeks to arouse the interest of students, based on a proposal that is based on motivation, knowledge and fun. This conclusion was realized when the software was tested at the Instituto dos Cegos, because there were much enthusiasm and attention from the participants.

- The main objective of this work was successfully achieved without loss of focus. The initial proposal was to create a computational resource that could meet the existent perspectives of inclusion and based on the authors and LDB. This way, it is believed that MapVoice serves most of the pedagogical proposals researched and based on this work.

- Evaluation of the software made during the test with the visually impaired was satisfactory. This conclusion is seen based on the positive feedback received from the participants and recorded on digital media during the test for further analysis. 
The free and available software on the market are prototypes that help the handicapped day to day in general aspects. With regard to the teaching/learning, obeying the PCN, no software was found that allows learning in the area of Cartography.

Through the creation and development of new technologies, visually impaired people require that studies be done to improve their living conditions, and consequently, their sociability. In Brazil, today, although there are still schools that are exclusively intended to receive students with some type of disability, this function has now become an obligation also for regular government schools, both municipal and of the state. This change has been happening to comply the Decree №. 3.956, October 8, 2001 that promulgated the Inter-American Convention on the Elimination of All Forms of Discrimination against Persons with Disabilities, seeks to consolidate the so desired society for all. The trend points ways for inclusion to be possible, to approximate regular and special teachings, until the system is unique, and for all.

In this way, the entrance of students with some type of deficiency in public schools has been more frequent, which previously only received students without any kind of disability. According to the MEC of 41,602 public schools, 8,608 already have a physical structure to receive visually impaired students. This requires the preparation, not only of the school for the reception of these students, but mainly the preparation of teachers of the public school system.

\section{ACKNOWLEDGMENTS}

The authors thank the Institute of the Blind Antônio Pessoa de Queiroz for providing the environment conducive to the test and all the employees who received us.

\section{REFERENCES}

Almeida, D.C.S. Geography and Inclusive/Special Education: the Visually Impaired case. 2008. $66 f$. Monograph - Federal University of Uberlândia, Uberlândia, Jan. 2008.

Alves, T. S. The use of the Google Maps application in the teach-learn process of Cartography: a public school experience. In: Annuals XV Brazilian Symposium of Remote Sensing - SBSR, Curitiba, PR, Brasil, INPE P.3408, 2011.

Brazil (1988) Constitution of the Brazilian Republic, Section which pactuates the education as a right for all. Available in: http://pactoensinomedio.mec.gov.br/images/pdf/constituicao educacao.pdf. Accessed in: May 11, 2016.

Brazil, Law no. 9.394, December 20, 1996 - Establishes the Guidelines and Bases of National Education, Available in: http://www.planalto.gov.br/ccivil 03/leis/L9394.htm. Accessed in: May 11,2016

Conde, A.J.M. Defining Blindness and Subnormal Vision. Benjamin Constant Institute. Available in: http://www.ibc.gov.br/?itemid=94. Accessed in: May 03, 2016. 
Enpeg. National Encounter of Geography Teaching Practice. Reseña de la celebración del, Porto Alegre, August 30 to September 2, 2009.

Fonseca, R. A. Spatial Perception Forms by blind children of the First Year of Basic Education of São Rafael State School. 1999. 139f. Dissertation. (Master's degree in Geography) - Geosciencies Institute of Federal University of Minas Gerais. Jun. 1999.

Libâneo, J.C. Pedagogy and pedagogues, for what? 6a ed. São Paulo: Cortez, 2002.

MEC (2006) Right to education: subsidies for management of educational systems: general orientations and legal marks / Organization: Ricardo Lovatto Blattes, 2a․ Ed, Brasília: MEC, SEESP, 2006. 343p.

Rossi, D. Visual Impairment: Challenges for Special Teaching and the Geography in the Classroom. In: REGO, Nelson et al. (org.) Geography and education: Generation of Ambiences. Porto Alegre: EDUFRGS, 2000.p.57-66.

Sá, E. D. de; Campos, I. M. de; Silva, M. B. C. Specialized Educational Attendance: Visual Impairment. Cromos Publishing House: Brasília, 2007. Available in: http://portal.mec.gov.br/seesp/arquivos/pdf/aee_dv.pdf. Accessed in: July 09, 2016.

Vasconcellos, R. Tactile cartography and the visually impaired: an assessment of the production steps and map use. 1993. 268p. Dissertation (Doctorate Thesis) - Geography Department of the F.F.L.C.H., São Paulo University, São Paulo, November 1993.

Ventorini, S. E. The experience as determining factor in the spatial representation of the visually impaired. 2007, 144f. Dissertation (Master Degree in Geography) - Department of Geography and Planning, Geosciences and Exact Sciences Institute of Rio Claro, Rio Claro, May 2007.

Ventorini, S.E; Freitas, M.I.C. Tactile Cartography: Elaboration of Courseware for the Visually Impaired. In: Annuals I Ibero American Child Cartography Symposium, UERJ, 2002. Rio de Janeiro, 07 to 10 of August. 10p. (CD-ROM) 